\title{
SISTEM KEWARISAN ADAT BATAK DI TAPANULI SELATAN
}

\author{
Fatahuddin Aziz Siregar* \\ Institut Agama Islam Negeri (IAIN) Padangsidimpuan \\ Email: fatahuddinazizsiregat@gmail.com
}

\begin{abstract}
Each indigenous community regulates the transfer of assets from heirs to heirs, because it is related to the primary needs in meeting the needs of life, and even relates to the dignity of a family in their customary community. As a society that calculates kinship lines from the men, according to Batak custom in South Tapanuli, wealth is also only passed on to male relatives, especially boys, who are seen as the successors of the clan and family pride. This system places a daughter as a party whose full living needs are borne by her husband so that she does not have the status of an heir. Even so there are other instruments that make room for girls to participate in receiving certain portions of the property left by their parents. Girls can accept olong ate, giving love that hinders the willingness of the boys to give up some of their rights so that girls can be protected. At the moment Olong Ate has a new meaning, if initially relies on the good wishes of boys who generally do not show their exceptions and do not leave any wealth at all, at this time olonhate becomes a necessity for boys to give a fair share. even to a girl is not equal to the share of a boy.
\end{abstract}

Keywords: Adat inheritance, Batak, South Tapanuli.

\begin{abstract}
Abstrak
Setiap masyarakat adat mengatur cara peralihan harta dari pewaris kepada ahli waris, sebab terkait dengan kebutuhan primer dalam memenuhi hajat hidup, bahkan berhubungan juga dengan martabat suatu keluarga dalam komunitas adatnya. Sebagai masyarakat yang menghitung garis kekerabatan dari pihak laki-laki, maka menurut adat Batak di Tapanuli Selatan harta juga hanya diwariskaan kepada kerabat laki-laki terutama anak laki-laki yang dipandang sebagai penerus marga dan kebanggaan keluarga. System ini menempatkan anak perempuan sebagai pihak yang kebutuhan hidupnya sepenuhnya menjadi tanggungan suaminya sehingga tidak berstatus sebagai ahli waris. Sekalipun demikian ada instrument lain yang memberi ruang bagi anak perempuan untuk turut menerima porsi bagian tertentu dari harta yang ditinggalkan oleh orang tuanya. Anak perempuan bias menerima olong ate, pemberian kasih sayang yang mengandalhan kerelaan pihak anak laki-laki untuk melepas sebagian haknya agar anak perempuan dapat tersantuni. Saat ini olong ate mendapat pemaknaan baru, jika pada awalnya berhantung kepada keinginan baik anak laki-laki yang pada umumnya justru tidak menunjukkan kepedualiannya dan sama sekali tidak menyisakan sedikitpun harta, saat ini olonhate menjadi suatu keharusan bagi anak laki-laki untuk memberi bagian yang layak kepada anak perempuan sekaipun tidak setara dengan bagian anak lakilaki.
\end{abstract}

Kata Kunci: Kewarisan adat, Batak, Tapanuli Selatan.

\section{Pendahuluan}

* Dosen Fakultas Syariah dan Ilmu Hukum Institut Agama Islam Negeri (IAIN) Padangsidimpuan. 
Sebagaimana masyarakat adat pada umumnya, masyarakat adat Batak di Tapanuli Selatan juga mempunyai aturan dalam hal peralihan kepemilikan harta warisan dari pewaris kepada para ahli waris. Secara prinsip sesungguhnya aturan peralihan harta warisan tersebut didasarkan pada sistem kekerabatan yang berlaku di masyarakat adat setempat. Menurut Hazairin hukum waris adat mempunyai corak tersendiri dari alam pikiran masyarakat yang tradisional dengan bentuk kekerabatan yang sistem keturunannya patrilinial, matrilinial, parental atau bilateral. ${ }^{1}$ Dalam hal ini dapat dikatakan bahwa yang berhak mendapatkan bagian dari harta warisan adalah pihak yang dianggap sebagai penerus kekerabatan atau pada masyarakat Tapanuli Selatan yang melanjutkan marga keluarga. Berikut ini pembahasan tentang kewarisan yang adat Batak yang meliputi asas-asas, ahli waris, besar bagian dan cara pewarisan menurut ketentuan adat Batak di Tapanuli Selatan.

\section{Asas-asas Hukum Kewarisan Adat}

1. Unilateral Patrilinial

Hukum waris adat pada prinsipnya terkait erat dengan struktur sosial kemasyarakatan di mana hukum tersebut tumbuh dan berkembang. Oleh karena itu, hukum waris adat erat hubungannya dengan sistem kekerabatan atau struktur sosial yaitu masyarakat hukum adat sebagai subyek hukum adat serta pengaruhnya terhadap harta kekayaan atau harta perkawinan yang ditinggalkan yang berada dalam masyarakat itu. Selain itu, hukum waris adat juga dipengaruhi oleh perubahan-perubahan sosial budaya di mana hukum adat itu hidup seperti kuat lemahnya hubungan antara masyarakat hukum adat dengan keluarga dan individu. ${ }^{2}$

Sebagaimana telah diuraikan pada bab terdahulu bahwa salah satu nilai budaya terkuat masyarakat Batak adalah nilai kekerabatan. Hukum warisan adat merupakan hukum yang langsung berkaitan dengan hubungan kekerabatan orang batak. Betapa pentingnya adat istiadat dan kekerabatan dalam kehidupan orang Batak dapat dilihat peranannya dalam menyelesaikan masalah-masalah konflik dalam masyarakat. Terkait dengan kekerabatan ini dalam hal kewarisan berlaku asas unilateral, yaitu suatu asas yang berarti bahwa peralihan harta warisan hanya berlaku untuk satu garis kekerabatan saja. Satu garis kekerabatan yang dimaksud tentu saja adalah garis kekerabatan laki-laki.

Pada masyarakat Batak secara umum, anak laki-laki disebut tampuk ni pasu-pasu, ihot ni ate-ate, tumtum ni siubeon. Artinya anak laki-laki itu adalah segalanya, sesuatu yang sangat berharga. Orang Batak akan berusaha dan melakukan berbagai upaya untuk mendapatkan seorang anak laki-laki. Jika tidak memiliki anak laki-laki diumpamakan sebagai na purpur tu angin na mayup tu

\footnotetext{
${ }^{1}$ Hazairin, Hukum Kewarisan Bilateral Menurut Al-Qur`an, (Jakrata: Tintamas,1982), cet. VI, h. 11

2 Dominikus Rato, Hukum Perkawinan dan Waris Adat di Indonesia, (Yogyakarta: Laksbang Pressindo, 2015), h. 112-113
} 
alogo, artinya terbang ke udara dan hanyut terbawa angin. ${ }^{3}$

Dalam hukum adat sistem ini disebut dengan kekerabatan patrilinial. Anak menghubungkan diri dengan ayahnya berdasarkan keturunan laki-laki. Baik laki-laki maupun perempuan menarik garis keturunannya ke atas hanya melalui penghubung yang laki-laki sebagai saluran darah. Setiap orang hanya menghubungkan dirinya kepada ayahnya saja, dan dari ayahnya kepada ayah dari ayahnya yaitu datuknya dan begitu seterusnya menghubungkan dirinya ke atas selalu menurut saluran atau penghubung yang laki-laki. Dengan demikian setiap orang Batak, hanya laki-laki yang mempunyai keturunan yang terdiri dari semua anak-anaknya, baik laki-laki maupun perempuan. Keturunan seorang hanya diteruskan oleh anak laki-lakinya saja. Sedangkan bila ia perempuan, menurut sistem patrilinial ini, tidak layak untuk menghasilkan keturunan bagi ayahnya. ${ }^{4}$ Dilihat dari berlakunya sistem kekerabatan pada masyarakat adat Tapanuli Selatan, maka kekerabatan pada wilayah ini tergolong pada sistem patrilinial murni, yaitu secara konsisten berpegang kapada prinsip bahwa hanya laki-laki saja yang bisa menjadi penerus keturunan. Sedangkan pada masuarakat patrilinial tidak murni perempuan bisa menjadi penerus keturunan dengan cara melakukan upacara adat sehingga ia dianggap laki-laki menurut perspektif adat. ${ }^{5}$

Dalam sistem kekerabatan ini, anak juga menghubungkan diri dengan kerabat ayah berdasarkan garis keturunan laki-laki secara unilateral. ${ }^{6}$ Dalam susunan masyarakat adat Tapanuli Selatan, keturunan dari pihak bapak (laki-aki) dinilai mempunyai kedudukan lebih tinggi dan mendapatkan hak-hak myang lebih banyak. Oleh karena itu jika seorang pewaris tidak meninggalkan anak lakilaki maka harta warisannya akan jatuh kepada kerabat laki-laki berdasarkan sistem kekerabatan ptrilinial tersebut dalam bingkai kekerabatan dalihan natolu.

Anak perempuan dalam sistem kewarisan adat Tapanuli Selatan tidak memperoleh bagian, Hal ini terkait dengan keberadaan anak secara adat tidak lagi berada di rumah ayahnya, tapi telah berpindah sepenuhnya secara adat ke keluarga besar suaminya. Sejak lama, tepatnya pada masa pemerintahan kolonial Belanda sebenarnya ada saja anggota masyarakat yang kadangkala merasa aturan ini tidak memenuhi rasa keadilan, kemudian memperkarakannya ke lembaga peradilan resmi. Misalnya kasus yang diajukan kepada landraad Padangsidimpuan pada tahun 1937. Ketika itu Landraad Padangsidimpuan menyidangkan perkara kewarisan yang mempersoalkan kedudukan anak perempuan yang tidak mendapat bagian harta warisan. Saat itu, tepatnya tanggal 10 Mei 1937 No. 21 yang dikuatkan Raad van Justitie Padang tanggal 13 Juanuari 1938 dinyatakan bahwa anak-anak perempuan bukan ahli waris dari bapaknya,

${ }^{3}$ HP Panggabean dan Richard Sinaga, Hukum Adat Dalihan Na Tolu tentang Hak Waris, (Jakarta: Dian Utama, 2004), h. 30

${ }^{4}$ Hazairin, Hendak Kemana Huium Islam, (Jakarta: Tintamas,1960), h. 6

5 A. Suriyaman Mustari Pide, Hukum Adat Dahulu, Kini, dan Akan Datang, (Jakarta: Prenamedia, 2015), h. 61

${ }^{6}$ Dewi Sulastri, Pengantar Hukum Adat, (Bandung: Pustaka Setia, 2015), h. 120 
terkecuali bila mereka dengan menyimpang dari ketentuan tadi harus dianggap sebagai ahli waris. Penyimpangan yang dimaksud bisa terjadi misalnya dikarenakan pewaris tidak mempunyai anak laki-laki. ${ }^{7}$ Sejalan dengan keputusan ini, pada tahun 1954 Pengadilan Tinggi Medan membuat Keputusan No. 50/ 1954 yang menguatkan keputusan Pengadilan Negeri Padangsidimpuan, tanggal 12 Desember 1953, No. 81/1953 bahwa janda tidak mewarisi tanah suami. ${ }^{8}$ Menurut sistem kewarisan adat yang berdasarkan kekerabatan patrilinial, pihak perempuan baik karena hubungan darah, yaitu anak perempuan, maupun karena perkawinan, yaitu isteri memang tidak mendapatkan bagian harta warisan.

Kemudian dapat ditambahkan bahwa menurut ketentuan hukum adat Tapanuli Selatan anak laki-laki yang lahir dari suatu perkawinan yang belum diadati-belum diselesaikan menurut hukum adat-tidak berhak mewarisi harta peninggalan orangtuanya. Ini yang disebut inda dihobaran manurut adat. Ada serangkaian upacara adat yang panjang untuk meresmikan perkawinan seorang anak dengan boru yang wajib dilaksanakan. Jika seremoni adat itu diabaikan maka perkawinan tersebutlah yang dikatakan sebagai inda dihobaran manurut adat.

2. Asas Individual

Dalam sistem kewarisan adat Tapanuli selatan seorang yang berhak mendapatkan porsi bagian dari harta warisan memiliki bagiannya tersebut secara utuh dan bersifat perorangan. Setelah diadakan pembagian harta warisan, maka setiap ahli waris dapat menguasai dan memiliki bagian harta warisannya untuk diusahakan dengan menginvestasikan atau mengolah harta tersebut, dipergunakan untuk kepentingan konsumtif, dijual kepada sesama ahli waris atau orang lain ataupun dihibahkan kepada orang yang dia kehendaki. Sistem mini sejalan dengan tradisi manjae, di mana seorang anak yang telah menikah dituntut untuk hidup mandiri, memperjuangkan kebutuhan hidupnya dengan berusaha sesuai dengan keahliannya.

Pada sistem hukum adat cara pewarisan dengan sistem individual ini selain karena sistem patrilinial disebabkan oleh tidak adanya yang berhasrat memimpin penguasaan atau pemilikan harta warisan secara bersama, karena para ahli waris tidak terikat lagi pada satu rumah kerabat atau rumah orang tua dan lapangan kehidupan masing-masing ahli waris telah tersebar ke berbagai wilayah pemukiman. ${ }^{9}$

Kebaikan sistem pewarisan individual ini antara lain adalah bahwa dengan memiliki harta secara pribadi maka para ahli waris dapat bebas menguasai dan memiliki harta warisan bagiannya untuk dipergunakan sebagai modal kehidupannya lebih lanjut tanpa bergantung kepada ahli waris lain. Setiap ahli

\footnotetext{
${ }^{7}$ Hilman Hadikusuma, Hukum Waris Adat, (Bandung: Citra Aditya Bakti, 2003), h. 70

8 M. Ali Boediarto, Hukum Waris: Kompilasi Abstrak Hukum Putusan Mahkamah Agung, (Jakarta: Penerbit Universitas Trisakti, 2012), h. 19-22

${ }^{9}$ Hilman Hadikusuma, op.cit., h. 25
} 
waris dapat melakukan tindakan hukum dengan melakukan berbagai transaksi bagiannya itu kepada orang lain untuk digunakan menurut kebutuhannya sendiri atau menurut kebutuhan orang yang berada di bawah tanggungannya.

Asas individual ini terasa lebih relevan untuk kondisi sekarang, karena harta yang dimilki seseorang merupakan harta pribadi hasil pencariannya sendiri. Masyarakat adat Batak Tapanuli Selatan sejak semula tidak mengenal pemilikan harta secara kolektif, dan sistem ini tetap berlaku hingga saat sekarang. Sistem kewarisan individual ini merupakan sistem yang diidealkan dan akan dipraktikkan secara nasional Masyarakat yang menggunakan sistem kolektif sekalipun saat ini telah banyak melakukan kewarisan dengan cara individual. Di daerah Minangkabau misalnya, pewarisan kolektif masih tetap bertahan, namun lapangannya sudah semakin menyempit. ${ }^{10}$

Kelemahan dari sistem ini ialah pecahnya harta warisan dan merenggangnya tali kekerabatan yang dapat berakibat timbulnya hasrat ingin memiliki kebendaan secara pribadi dan mementingkan diri sendiri. Sistem individual dalam pewarisan dapat menjurus ke arah nafsu yang bersifat individualisme dan materialisme. Akibat lebih lanjut dari sifat yang hanya peduli dengan diri sendiri ini kemudian timbulnya konflik antara sesama anggota keluarga pewaris.

3. Asas Keutamaan

Asas ini menentukan bahwa ada prioritas penerima harta warisan diantara para ahli waris, bahwa ketika yang diprioritaskan masih hidup maka ahli waris yang lain belum berkesempatan untuk memperoleh porsi bagian tertentu dari harta warisan. Asas ini sesungguhnya dapat ditemukan pada setiap sistem kewarisan, mengingat hubungan pewaris dengan para ahli waris berbeda satu sama lain, ada yang lebih dekat dibanding yang lain. ${ }^{11}$ Dalam hukum kewarisan Islam misalnya dikenal sistem hijab, ahli waris yang lebih dekat (hajib) mendindingi ahli waris yang lebih jauh (mahjub). Ada yang terdindingi untuk mendapatkan bagian yang banyak menjadi lebih sedikit karena ada ahli waris yang lebih utama mengingat hubungannya yang lebih dekat dengan pewaris (terhijab nuqsan), ada pula yang terdindingi dari mendapat sejumlah bagian tertentu menjadi sama sekali tidak mendapatkan bagian (terhijab hirman).

Jika pada masyarakat yang menganut asas penerimaan kolektif sebagaimana pada masyarakat Minangkabau, asas keutamaan ini juga dianut, maka pada masyarakat adat yang berpegang kepada asas individual, sistem keutamaan dimaksud lebih dimungkinkan terjadi. Menurut penulis asas keutamaan ini merupakan konsekuensi logis dari asas individual sebagaimana juga berlaku pada sistem kewarisan Islam. Oleh karena ahli waris memiliki bagiannya secara utuh dan bersifat perorangan, tentu berakibat kepada

10 Amir Syarifuddin, Pelaksanaan Hukum Kewarisan Islam dalam Lingkungan Adat Minangkabau, (Jakarta: Gunung Agung, 1984), h. 235

${ }^{11}$ Amir Syarifuddin, Op. Cit., h. 235. 
terhalangnya orang lain untuk memilikinya apalagi kewarisan adat tidak mengenal legitiem portie, tidak ada jumlah bagian tertentu yang membatasi bagian orang yang diutamakan tersebut.

Pada dasarnya menurut hukum adat secara umum golongan pertama dalam keutamaan ialah kelompok yang terdiri dari semua keturunan si pewaris, yakni keturunan yang masih hidup pada saat dilakukannya pembagian harta peningggalan dalam sistem kewarisan individual, atau pada saat meninggalnya pewaris dalam sistem kewarisan kolektif. ${ }^{12}$

Apabila golongan pertama ini tidak ada, dalam ari pewaris tidak mempunyai keturunan yang masih hidup, yang dikenal dengan istilah punah, maka kelompok keutamaan kedua tampil untuk menerima bagian dari harta warisan, yaitu orang tua pewaris. Sebenarnya orangtua adalah ayah dan ibu, akan tetapi karena masyarakat berlaku juga asas patrilinial pada masyarakat adat Tapanuli Selatan, maka yang berhak menerima bagian sebagai kelompok keutamaan kedua hanyalah ayah saja, ibu tidak menerima bagian.

Apabila golongan keutamaan kedua ini juga sudah tidak ada, telah meninggal dunia terlebih dahulu, maka tampil sebagai pengganti golongan ketiga yaitu saudara pewaris, dalam hal ini tentunya hanya saudara laki-laki pewaris. Jika golongan ketiga ini juga kosong, maka gliran berikutnya adalah orangtua dari orangtua pewaris, dan manakala ada tempat yang kosong dalam kelompok tersebut maka tempat yang kosong itu akan diduduki oleh keturunan yang masih hidup dari orang yang tempatnya kosong tersebut, berarti dalam hal ini giliran berikutnya adalah paman dari pewaris.

Bagian para ahli waris pada dasarnya adalah sama, akan tetapi pada kenyataannya ada orang-rang yang memperoleh hasurungan. Hasurungan itu disebabkan tanggung jawab yang lebih besar dalam merawat orang tua pada usianya yang lanjut. Anak laki-laki tertua boleh dikatakan merupakan timbalan ayahnya dalam tugas-tugas kemasyarakatan dan keluarga. Tugas ini dilimpahkan kepadanya apabila ayahnya berhalangan. Oleh karena dia yang tertua, dia pula yang banyak tanggung jawab mengayomi keluarganya termasuk melindungi dan mencukupi keperluan orang tuanya. Itu sebabnya anak tertua ini memiliki hasurungan dari saudara-saudaranya yang lain. ${ }^{13}$

Demikian pula dengan anak yang paling bungsu yang menjadi tumpuan perawatan orangtuanya, karena orangtua tersebut tinggal bersama anak bungsu. Dalam hal ini, anak bungsu beralasan untuk mendapat hasurungan dalam pembagian harta warisan. Kenyataan membuktikan bahwa hal tersebut bukanlah menutup kemungkinan anak-anak yang ditengah untuk memperoleh hasurungan. Karena dalam hal si sulung dan si bungsu tidak hidup dikampung halaman atau kesehatan rohaninya terganggu, maka anak yang tengah, anak haldungan, menjadi

${ }^{12}$ Hazairin, Hukum Kewarisan Bilateral menurut Alqur `an dan Hadith, (Jakarta: Tintamas, 1982) cet. VI, h. 20-21

13 Ibid, h. 534 
tumpuan hidup orangtuanya. Dalam hal ini anak haldungan itupun berhak memperoleh hasurungan.

\section{Ahli Waris}

Semua ahli waris dalam hukum adat Tapanuli Selatan adalah kerabat dari pihak laki-laki sesuai dengan sistem kekerabatan patrilinial. Perempuan tidak memiliki hak sedikitpun dari harta warisan. Mereka sebenarnya dapat memperoleh bagian harta, akan tetapi bukan sebagai harta warisan. Berikut ini adalah urutan para ahli waris yang berhak menerima harta warisan:

1. Anak turunan laki-laki dari pewaris

2. Ayah dari pewaris

3. Saudara laki-laki seayah dari pewaris

4. Kakek pewaris

5. Saudara laki-laki dari ayah pewaris

6. Ripe, orang-orang yang semoyang, semarga, dan sehuta dengan pewaris

7. Huta, desa ${ }^{14}$

Apabila ahli waris sampai pada tingkat ke-6 (butir nomor 6 di atas) tidak ada maka harta peninggalan itu jatuh pada huta yang dalam hal ini kepada Raja Pamusuk sebagai penguasa adat di huta yang bersangkutan. Raja Pamusuk sebagai penguasa adat dalam pergaulan hidup dan kehidupan masyarakat dalihan natolu adalah pendiri huta yang membuka bona bulunya dan telah diresmikan oleh Raja Panusunan Bulung. Sebelum penjajah Belanda bercokol di daerah ini, sebutan Raja Panusunan Bulung sudah ada sebagai penguasa adat di wilayah kekuasaannya yang meliputi bona bulu parhutaon.

Ripe adalah keluarga batih, keluarga inti yaitu satuan masyarakat terkecil dalam susunan masyarakat Tapanuli Selatan. Ripe dapat juga berarti isteri misalnya si A adalah isteri si B, dapat dikatakan si A adalah ripe si B. Agar tidak terjadi kerancuan dalam pemakaian ripe, sebagai ahli waris maka perlu dijelaskan siapa-siapa yang berhak menjadi ahli waris, sesuai dengan sistem satuan kemasyarakatan yang genealogis, berdasarkan turunan yang hanya melewati orang laki-laki saja.

Ripe sebagai ahli waris adalah satuan kemasyarakatan yang terkecil, terdiri dari suami isteri yang mandiri, sudah mempunyai rumah tangga sendiri termasuk anak-anak mereka yang lahir dari perkawinan itu belum menikah dan manjae, mandiri.

Saama terdiri dari laki-laki seayah, baik yang belum ataupun yang sudah menikah. Laki-laki yang seayah seibu disebut saama saina. Mereka yang seayah tetapi berlainan ibu disebut saama paasing-asing ina. Mereka ini mempunyai hak yang sama dalam mewarisi harta ayah mereka.

Saompu adalah mereka yang menjadi cucu kandung dari seorang kakek

14 Parsadaan Marga Harahap Dohot Anakboruna di Jakarta Sahumaliangna, Horja: Adat Istiadat Dalihan Na Tolu, (Bandung: Grafitri, 1993), h. 532 
yang membentuk satu satuan kemasyarakatan yang disebut satuan ompung.

Saparamaan adalah mereka yang tergabung dalam satuan kekerabatan yang terdiri dari ayah kakek, kakek bersaudara, anak-anak dari kakek bersaudara, para cucu dari para kakek bersaudara. Mereka ini semua tergabung dalam satuan kekerabatan saparamaan.

Saparompuan satuan-satuan saparamaan yang berasal dari keturunan satu cikal bakal kerabat itu dalam berbagai tingkatan tutur ke atas maupun ke bawah. (ompung, amang, anak, bor, anggi, angkang, dan pahompu) yang membentuk satu kesatuan kekerabatan saparompuan atau sakahanggi

Sabona atau sahaturunan merupakan ustau satuan dari saparompuan yang merupakan satuan kekerabatan yang paling besar dalam kekerabatan kahanggi

Satu hal yang perlu pula dikemukakan disini adalah tentang tidak adanya hak waris anak-anak yang lahir diluar nikah menurut hukum adat. Anak-anak ini disebut anak na dapot di ladang yang tidak berhak pula memakai marga ayahnya, melaikan dia memakai marga ibunya tetapi tetap tidak menjadi ahli waris pihak orangtua ibunya.

Dari uraian di atas jelas tampak bahwa peranan ayah, dalam hal ini pihak laki-laki mempunyai peranan yang menentukan. Ayah bertanggung jawab atas segala untung rugi dalam kehidupan kekerabatannya dan sekaligus ayah pula yang berkewajiban menangkal segala bahaya yang mengancam keluarga.

Di dalam masyarakat Batak ada kemungkinan melakukan pewarisan sewaktu seorang ayah masih hidup. Pewarisan demikian itu dilakukan ketika anaknya manjae dengan memberikan arta panjaean sebagai modal pertama hidup mandiri sebagai ripe. Kelak sesudah ayah ini meninggal dan apabila ada ahli waris lain yang berhak atas peninggalannya, maka arta panjaean ini selalu dapat diperhitungkan.

Seperti telah disinggung sebelumnya seorang janda bukan merupakan ahli waris dari suaminya yang telah meninggal dunia. Lebih dari, harta bawaan dari seorang isteri yang didapatnya sebelum melangsungkan perkawinan, juga terhitung sebagai harta suami. Ini sebagai konsekuensi dari kawin manjujur, di mana diatur bahwa seorang isteri telah terlepas dari ikatan keluarga aslinya, dan melebur ke dalam keluarga suaminya. Termasuk juga meleburkan harta bawannya ke harta suaminya. Bahkan ketika suaminya telah meninggal dunia, dia tetap berkedudukan di tempat kerabat suami. Aturan berlaku bagi setiap perempuan yang ditinggal mati suaminya, baik ia memiliki anak dari suaminya tersebut maupun tidak. Ia tidak boleh kembali lagi kepada kerabat aslinya. Ia tidak bebas menentukan sikap tindaknya, oleh karena segala sesuatu harus mendapat persetujuan kerabat almarhum suaminya. Sebagai bentuk kompensasi, sekalipun dia bukan merupakan ahli waris dari almarhum suaminya, seorang janda selama hidupnya berhak menggunakan harta suami dalam batas kebutuhan hidupnya. ${ }^{15}$

${ }^{15}$ Hilman Hadikusuma, Op. Cit., h. 84-85 


\section{Besarnya Bagian Ahli Waris}

Hukum adat pada umumnya tidak mengenal cara pembagian dengan perhitungan matematis, tetapi selalu didasarkan atas pertimbangan mengingat wujud benda dan kebutuhan waris bersangkutan. ${ }^{16}$ Hukum adat Batak di Tapanuli Selatan juga menerapkan cara yang sama dengan hukum adat di daerah lain. Tidak dikenal prinsip legitieme portie, atau hak mutlak, sebagaimana diatur dalam hukum waris Barat atau hukum waris Islam. Dalam hukum waris Islam pembagiannya dilakukan secara terperinci dengan perhitungan yang sangat matematis. Setiap ahli waris memiliki kadar bagian tertentu yang disebut sebagai al-furud al-muqaddarah.

Porsi bagian para ahli waris didasarkan kepada prinsip persamaan. Namun tidak berarti bahwa setiap ahli waris akan mendapatkan bagian harta warisan dalam jumlah yang sama, dengan nilai harga yang sama atau menurut banyaknya bagian yang sudah tertentu. Seperti telah dijelaskan pada asas kewarisan adat Batak Tapanuli Selatan, pada kenyatannya ada orang-orang tertentu yang memperoleh hasurungan (keutamaan). Anak tertua sebagai penerima hasurungan tersebut akan mendapatkan porsi bagian melebihi saudaranya yang lain, karena merupakan pengganti orang tua bagi adikadiknya. ${ }^{17}$ Pertimbangan hasurungan dapat juga karena yang bersangkutan telah merawat orang tuanya sebelum meninggal dunia.

Sebagai contoh, misalnya seorang pewaris meninggal dunia dan meninggalkan 3 orang anak laki-laki, dan 2 orang anak perempuan, yaitu: Miduk Hasibuan (39 Tahun), Tagor Hasibuan (34 Tahun), Ranto Hasibuan (31 Tahun), Lengga br Hasibuan (28 tahun), dan Lumongga br Hasibuan (25 Tahun). Ayah mereka Alm. Dimro Hasibuan meninggal harta senilai Rp. 520.000.000,- Maka cara pembagiannya adalah:

Langkah pertama, dikeluarkan dulu bagian anak perempuan sebagai olong ate. Bagian menurut olong ate ini tidak tertentu, misalnya mereka bersepakat untuk memberi kepada anak perempuan masing-masing - Lengga br Hasibuan : : Rp. 20.000.000,-

- Lumongga br Hasibuan $\quad$ : Rp. 20.000.000,Jumlah Rp. 40.000.000,-

Sisa harta berjumlah Rp. 520.000.000 - Rp.40.000.000,- = Rp.480.000.000. Uang tersebut pada dasarnya dibagi secara merata kepada 3 orang anak laki-laki sebagai ahli waris yang sesungguhnya. Jika dibagi rata seharusnya setiap anak laki-laki akan memperoleh bagian sebesar Rp.160.000.000,- Namun berdasarkan penilain kerabat dekat, terutama unsur dalihan na tolu, anak pertama layak memperoleh hasurungan karena telah memelihara adik-adiknya, kemudian

\footnotetext{
${ }^{16}$ Ibid., h. 105

17Parsadaan Marha Harahap Dohot Anak Boruna Jakarta Sahumaliangna, o.pcit. h. 534
} 
disepakati bahwa distribusi sisa harta tersebut adalah sebagai berikut:

- Miduk Hasibuan : Rp. 220.000.000,-

- Tagor Hasibuan : : Rp. 150.000.000,-

- Ranto Hasibuan : : Rp. 150.000.000,-

Bentuk harta warisan seringkali tidak dapat dibagi secara matematis karena merupakan sawah atau kebun. Dalam kondisi demikian harta akan dibagi menurut kepantasan yang jika dinilai dengan uang kira-kira seperti contoh di atas. Jumlah bagian perorang bisa sangat bervariasi, bergantung kepada kondisi dan kepantasan menurut ukuran suatu keluarga.

\section{Cara Pewarisan}

Dalam hal pusaka disebut ada dua istilah yaitu manean dan mamusakai. Manean berlangsung dengan cara paksa, tetapi mamusakai berlangsung secara turun-temurun tanpa paksaan. Dalam tean-manean ada dua cara, yaitu tean jongjong. Artinya seorang yang idak mempunyai anak laki-laki mengangkat anak laki-laki abangnya secara adat. Anak ini lah kelak yang manean hartanya. Ada lagi tean mate, yaitu mambagi-bagi harta peninggalan orang yang mate punu. Orang yang meninggal tanpa memiliki keturunan. Kerabat orang yang $p u n u$ tu membagibagi harta peninggalan orang punu sepengetahuan Raja Pamusuk. Ada kepercayaan orang Batak bahwa manean harta orang yang punu akan membawa akibat yang tidak baik. Dipercayai bahwa harta semacam ini marbegu itu sebabnya mereka tidak bergairah untuk manean orang yang punu.

Cara pewarisan lain semasa hidup dilakukan dengan wasiat. Ayah yang sedang sakit dapat memberikan wasiat tentang cara pewarisan atas hartanya kepada ahli warisnya. Hal ini dilakukan karena kemauan sendiri, atau karena diingatkan oleh ahli warisnya untuk memberikan wasiat pembagian warisannya kelak. Wasiat ini dibuat pula apabila pewaris itu tidak mempunyai anak laki-laki atau sama sekali tidak mempunyai keturunan. Wasiat ini mempunyai kekuatan hukum. Inilah yang disebut tona na mate inda tola muba. Wasiat ini dapat menggugurkan pesan-pesan sebelumnya yang bertentangan dengan wasiat itu. Pemberian wasiat ini haruslah disaksikan oleh kerabatnya dan ahli waris tersebut. Wasiat itu ada yang dilakukan juga secara tertulis yang ditanda tangani pewaris dan saksi-saksi yang sah dari Dalihan Na Tolu.

Ada banyak harta yang diwariskan sebagai harta peninggalan yang dibagi oleh ahli waris setelah pewaris meninggal dunia. Harta lisan itu adalah: arta panjaean, arta holong ni ate dan arta na niduk-iduk. Semua harta yang paling berarti untuk dibagi-bagi oleh ahli waris adalah:

Tanah yang terdiri dari:

1. Sawah yang dibuka sendiri oleh pewaris dan sawah warisan dari leluhur pewaris yang diusahakan sendiri.

2. Kebun (hauma) yang dibuka dan dikerjakan oleh pewaris.

3. Pekarangan tempat pertapakan rumah atau sopo pewaris. 
4. Rumah terlepas dari tanah pertapakannya. Rumah dapat diwarisi oleh beberapa orang. Ini dapat terjadi apabila rumah tersebut didirikan oleh beberapa orang, sehingga ada hak orang lain selain ahli waris dari pewaris itu.

5. Ternak, kerbau, kuda, kambing, ayam, bebek, dan sapi. Ternak besar, kerbau, karena harganya yang mahal ada kemungkinan menjadi milik beberapa orang karena dibeli secara bersama-sama. Pembagian itu rata porsinya, sekaligus juga mereka yang mendapat bagian itu menanggung bersama kerugian yang ditimbulkan oleh kerbau, misalnya kerbau itu merusak tanaman orang lain.

6. Pohon yang menghasilkan buah dan getah merupakan pohon yang diperhitungkan pembagiannya (misalnya karet, kelapa, durian, mangga, slak, langsat, dll.) dengan tidak mengabaikan pohon lain yang tidak bergetah dan berbuah tetapi dapat menghasilkan seperti pohon/ rumpun bambu. Barangbarang warisan berupa pohon ini diperhitungkan secara terpisah, artinya terpisah dari tanah tempat pohon-pohon itu berbuah. Sering terjadi kasus hukum dalam kekerabatan Dalihan $\mathrm{Na}$ Tolu, lahan kepunyaan bersama tetapi tanamannya milik perseorangan atau sebaliknya. ${ }^{18}$

7. Piutang dapat berupa uang, barang, dan tenaga. Termasuk dalam piutang dalam bentuk uang adalah pembayaran uang tebusan barang-barang yang di gadai. Piutang berupa barang antara lain apabila ada orang-orang yang pernah marsali kepada pewaris, sedangkan piutang tenaga berupa tenaga dalam kaitannya dengan marsialap ari.

Hak dan kewajiban senantiasa tidak dapat dipisahkan, demikian halnya juga dengan harta warisan. Harta warisan belum dapat dibagi segera setelah pewaris meninggal, karena harta warisan itu masih mempunyai beban. Beban harta warisan itu ialah pemanfaatan harta warisan untuk menghidupi janda, anakanak laki-laki dan perempuan yang belum menikah atau anak-anak yang sudah menikah, tetapi belum manjae. Harta itu merupakan kelanjutan kemudahan yang disediakan pewaris setelah ia meninggal untuk menghidupi keluarganya. Harta warisan itu baru dapat dibagi apabila jandanya meninggal dunia dan setelah semua biaya pemakaman serta pelaksanaan semua wasiat-wasiatnya yang lain dibereskan. Sisa dari semua pengeluaran itulah yang dapat dibagi sebagai harta warisan.

Kedudukan perempuan dalam masyarakat Batak sangat penting, bahkan menentukan. Karena wanitalah yang menentukan adanya sistem kekerabatan Dalihan $\mathrm{Na}$ Tolu. Mora adalah keluarga isteri yang sangat dihormati karena selain dipandang memiliki sahala, juga merupakan sumber kehidupan yang melahirkan anak dan boru. Demikian juga adanya unsur anak boru dalam sistem kekerabatan yang disebabkan kehadiran wanita di pihak kerabat suaminya. Anak boru sebagai pihak yang mengambil isteri dari pihak mora merupakan tulan punggung dalam segala sei kemasyarakatan adat pihak mora. Selain itu, dalam setiap pembicaraan dalam musyawarah adat, giliran pertama yang berbicara adalah kaum wanita.

${ }^{18}$ Ibid., h. 535 
Pada hakekatnya peranan boru dalam kehidupan kekerabatan bukan saja penting, tetapi malahan sangat menentukan.

Besarnya peranan boru di dalam kehidupan kekerabatan orang Batak memberikan kesan adanya keunikan tradisi masyarakat tersebut. Betapa tidak, karena boru yang sesungguhnya keluar dari kerabat ayahnya yang masuk secara total ke dalam kerabat suaminya. Di atas kertas seolah-olah habislah peranan boru di dalam kehidupan kekerabatan pihak keluarga ayahnya. Kenyataannya tidaklah demikian, karena justru boru yang telah menikahlah yang dapat memberikan peranan yang menentukan dalam kehidupan kekerabatan keluarga ayahnya.

Walaupun hukum warisan masyarakat Batak menurut garis ayah, garis laki-laki, namun tidak berati boru tidak memperoleh harta dari pihak ayahnya. Perolehan harta itu memang tidak bernama warisan, tetapi berupa honon ni ate atau pangusayang (pauseang) berupa pemberian barang-barang ketika dia menikan dan abit na so ra buruk berupa pemberian tanah yang boleh dimanfaatkannya selama hidupnya.

Sudah menjadi hukum alam bahwa manusia terus berkembang dan berubah. Sejalan dengan perubahan itu maka terjadi pula perubahan dalam berbagai segi tradisi kebudayaannya, termasuk di dalamnya hukum-hukum adat yang berlaku senantiasa tidak tertutup untuk menerima perubahan. Berangkat dari kenyataan itu, maka tidak mungkinlah untuk melaksanakan segala sesuatu yang telah ditentukan oleh leluhur dilaksanakan secara konsekwen. Usaha untuk memberlakukan aturan leluhur secara murni dan konsekwen sebagaimana adanya ketika aturan itu untuk pertama kali diciptakan dan diberlakukan, merupakan usaha yang justru dapat mematikan tradisi itu untuk selama-lamanya.

Ada beberapa faktor yang menyebabkan terjadinya perubahan kewarisan adat Batak di Tapanuli Selatan, di antaranya:

1. Letak georafis. Masyarakat Batak di Tapanuli Bagian Seatan berbatasan dengan wilayah Sumatera Barat. Secara umum masyarakat ini mendapat pengaruh dari budaya Minagkabau, terutama wilayah yang berbatasan langsung misalnya daerah Pakantan dipengaruhi oleh budaya Minangkabau yang bercorak matrilinial dalam hal pemberian hak kepada anak perempuan. Ini tidak ditemukan dalam adat Batak.

2. Penduduk yang mayoritas beragama Islam mendapat pengaruh kuat dari hukum Islam yang memberi porsi bagian kepada anak perempuan. Sebagian masyarakat membagi persis sebagaimana ketentuan hukum Islam, sebagian lagi belum sepenuhnya menurut faraid tapi setidaknya sudah mendapat pengaruh dari hukum Islam. Hukum Islam bahkan merupakan faktor utama penyebab pergeseran kewarisan adat Batak di Tapanuli Selatan. ${ }^{19}$

3. Politik mengubah sistem kepemimpinan tradisional ke sistem kepemimpinan yang demokratis sesudah kemerdekaan. Fungsi Raja Pamusuk sebagai kepala

${ }^{19}$ Fatahuddin Aziz Siregar, Hukum Islam dalam Pergeseran Kewarisan Adat Batak di Tapanuli Selatan, (Pascasarjana IAIN Imam Bonjol Padang: Disertasi tidak diterbitkan, 2016), hlm. 400. 
pemerintahan di desa diganti oleh Kepala Kampung dan fungsi Kepala Kuria atau Kepala Luat sebagai kepala pemerintahan wilayah yang membawahi desa-desa diganti oleh Ketua Dewan Negeri yang dipilih oleh rakyat. Perubahan ini telah mengubah secara drastis tatanan masyarakat adat di batak, namun keturunan Raja Pamusuk, Kepala Kuria dan Kepala Luat masih dihormati orang sebagai pemuka adat.

4. Ekonomi, berupa pemberian harta kepada anak perempuan apabila seseorang tidak mempunyai anak laki-laki, atau menghabiskan harta untuk membiayai sekolah anak-anaknya, sehingga tidak ada lagi harta yang akan dibagi oleh ahli waris. Ini sekaligus merupakan pengaruh modernisasi yang lebih mengutamakan ilmu dibandingkan dengan harta, dan mengesampingkan arti spritual dan magis dari harta warisan.

5. Faktor sosial, yaitu pemanfaatan harta untuk kepentingan bersama atau bahkan kepentingan masyarakat yang lebih luas, sehingga harta warisan itu tidak dibagikan kepada para ahli waris.

\section{Kesimpulan}

Sejalan dengan system kekerabatan patrilineal yang dianut oleh masyarakat Tapanuli Selatan, secara adat kewarisan bertumpu kepada pihak lakilaki. Harta warisan menjadi milik penerus marga, yaitu anak laki-laki. Anak perempuan tidak mendapat sedikitpun bagian harta dari orang tuanya. Hanya saja tetap ada solusi yang memberi porsi tertentu dari harta tersebut melalui instrumen lain, yaitu olong ate, suatu bentuk pemberian sebagai tanda kasih sayang seorang saudara laki-laki kepada saudara perempuannya. Olong atde ini tentu saja tidak menetapkan jumlah bagian tertentu yang pasti dan terukur, sepenuhnya diserahkan kepada kerelaan saudara laki-laki tersebut.

Olong ate ini kelihatannya mirip dengan wasiat wajibah dalam hukum Islam. Sebuah solusi yang memungkinkan banyak pihak menerima bagian dari harta warisan yang secara system kewarisan sesungguhnya tidak termasuk ahli waris, namun rasa keadilan menuntut untuk memberi porsi bagian kepada orang tersebut, seperti anak angkat, anak di luar nikah, bahkan ada yang memberi kepada kerabat berbeda agama.

\section{Daftar Pustaka}

A. Suriyaman Mustari Pide, Hukum Adat Dahulu, Kini, dan Akan Datang, Jakarta: Prenamedia, 2015.

Amir Syarifuddin, Pelaksanaan Hukum Kewarisan Islam dalam Lingkungan Adat Minangkabau, Jakarta: Gunung Agung, 1984.

Dewi Sulastri, Pengantar Hukum Adat, Bandung: Pustaka Setia, 2015.

Dominikus Rato, Hukum Perkawinan dan Waris Adat di Indonesia, Yogyakarta: Laksbang Pressindo, 2015.

Fatahuddin Aziz Siregar, Hukum Islam dalam Pergeseran Kewarisan Adat Batak di Tapanuli Selatan, (Pascasarjana IAIN Imam Bonjol Padang: Disertasi tidak 
ADHKI: Journal of Islamic Family Law

diterbitkan, 2016.

Hazairin, Hendak Kemana Huium Islam, Jakarta: Tintamas,1960.

Hukum Kewarisan Bilateral menurut Alqur'an dan Hadith, Jakarta: Tintamas, 1982.

Hilman Hadikusuma, Hukum Waris Adat, Bandung: Citra Aditya Bakti, 2003.

HP Panggabean dan Richard Sinaga, Hukum Adat Dalihan Na Tolu tentang Hak Waris, Jakarta: Dian Utama, 2004.

M. Ali Boediarto, Hukum Waris: Kompilasi Abstrak Hukum Putusan Mahkamah Agung, Jakarta: Penerbit Universitas Trisakti, 2012.

Parsadaan Marga Harahap Dohot Anakboruna di Jakarta Sahumaliangna, Horja: Adat Istiadat Dalihan Na Tolu, Bandung: Grafitri, 1993 